\title{
Patient safety climate from the nursing perspective
}

\author{
Clima de segurança do paciente na perspectiva da enfermagem \\ Clima de seguridad del paciente en la perspectiva de la enfermaría
}

\section{Vanessa Leal Lira' \\ ORCID: 0000-0003-1541-1876 \\ Sônia Maria de Araújo Campelo' ORCID: 0000-0003-0835-4789}

Nayra Ferreira Lima Castelo Branco' ORCID: 0000-0002-2569-7647

Herica Emilia Félix de Carvalho" ORCID: 0000-0002-5913-8886

Denise de Andrade" ORCID: 0000-0002-3336-2695

Adriano Menis Ferreira"'I ORCID: 0000-0002-4054-768X

Ivonizete Pires Ribeiro' ORCID: 0000-0003-0737-5430

'Universidade Estadual do Piauí. Teresina, Piauí, Brazil. "Universidade de São Paulo. Ribeirão Preto, São Paulo, Brazil. II' Universidade Federal do Mato Grosso do Sul. Pioneiros, Mato Grosso do Sul, Brazil.

How to cite this article: Lira VL, Campelo SMA, Castelo Branco NFL, Carvalho HEF, Andrade D, Ferreira AM, et al. Patient safety climate from the nursing perspective. Rev Bras Enferm. 2020;73(6):e20190606. doi: http://dx.doi.org/10.1590/0034-7167-2019-0606

\section{Corresponding author: Herica Emilia Félix de Carvalho E-mail: herica_emilly@hotmail.com.br}

EDITOR IN CHIEF: Antonio José de Almeida Filho ASSOCIATE EDITOR: Fátima Helena Espírito Santo

\section{ABSTRACT}

Objective: To analyze the patient safety climate in intensive care units from the nursing perspective. Methods: Cross-sectional study developed with 87 nursing professionals working in three Intensive Care Units of a public hospital for emergency services in Piauí from October to November 2018. The study used a validated Safety Attitudes Questionnaire (SAQ). In the inferential analysis, the Student's t-test, Mann-Whitney, and Kruskal-Wallis were performed. Results: The total SAQ score obtained a mean of 68.57 . In analyzing the scores obtained for each domain in the general SAQ, the Job Satisfaction, and Teamwork Climate domains were those that obtained the highest scores, and the lowest score was for the Perception of Hospital Management domain. Conclusion: The safety attitudes assessed from the perspective of the nursing team proved to be unfavorable.

Descriptors: Patient Safety; Intensive Care Units; Nursing; Safety Management; Quality of Health Care.

\section{RESUMO}

Objetivo: Analisar o clima de segurança do paciente em unidades de terapia intensiva na perspectiva da enfermagem. Métodos: Estudo transversal desenvolvido com 87 profissionais de enfermagem que atuam em três Unidades de Terapia Intensiva de um hospital público de urgência do Piauí no período de outubro a novembro de 2018. Utilizou-se um questionário validado de Atitudes de Segurança - Safety Attitudes Questionnaire (SAQ). Na análise inferencial, foram realizados o Teste t de Student, Mann-Whitney e Kruskal-Wallis. Resultados: O escore do SAQ total obteve média de 68,57. Em análise dos escores obtidos para cada domínio no SAQ geral, os domínios Satisfação no Trabalho e Clima de Trabalho em Equipe foram os que obtiveram os escores mais altos e o escore mais baixo foi para o domínio Percepção da Gerência do Hospital. Conclusão: As atitudes de segurança avaliadas sob a perspectiva da equipe de enfermagem mostraram-se desfavoráveis.

Descritores: Segurança do Paciente; Unidades de Terapia Intensiva; Enfermagem; Gestão da Segurança; Qualidade da Assistência à Saúde.

\section{RESUMEN}

Objetivo: Analizar el clima de seguridad del paciente en unidades de terapia intensiva en la perspectiva de la enfermaría. Métodos: Estudio transversal desarrollado con 87 profesionales de enfermaría que actúan en tres Unidades de Terapia Intensiva de un hospital público de urgencia de Piauí en el período de octubre y noviembre de 2018. Ha sido utilizado un cuestionario validado de Actitudes de Seguridad - Safety Attitudes Questionnaire (SAQ). En el análisis inferencial, han sido realizados el Teste t de Student, Mann-Whitney e Kruskal-Wallis. Resultados: La calificación del SAQ total obtuvo media de 68,57. En análisis de las calificaciones obtenidas para cada dominio en el SAQ general, los dominios Satisfacción en el Trabajo y Clima de Trabajo en Equipo han sido los que obtuvieron las calificaciones más altas y la calificación más baja ha sido para el dominio Percepción de la Gerencia del Hospital. Conclusión: Las actitudes de seguridad evaluadas bajo la perspectiva del equipo de enfermaría se ha mostrado desfavorables.

Descriptores: Seguridad del Paciente; Unidades de Terapia Intensiva; Enfermaría; Administración de la Seguridad; Calidad de la Asistencia a la Salud. 


\section{INTRODUCTION}

By definition, patient safety consists of reducing the risk of unnecessary damage related to health care, to the minimum acceptable. It is common for studies to treat patient safety culture and climate as synonyms. However, both have their particularities. The patient safety culture is a component of the organizational culture, which involves shared values, standards, and procedures related to safety within an organization, department, or team ${ }^{(1-2)}$.

The safety climate is a measurable component of the safety culture and can be assessed through the perception of professionals and is considered a starting point for health institutions to identify problem points, supporting the implementation of interventions ${ }^{(3)}$.

The agreement in the perceptions of the patient safety climate indicates positive interactions between professions, while divergent scores can indicate a dysfunctional culture of patient safety. An unfavorable or low patient safety climate may be related to higher rates of complications and incidents involving the increased occurrence of Adverse Events (AE), medication errors, readmissions, and more extended hospital stays, among others. On the other hand, a positive patient safety climate is associated with higher safety performance ${ }^{(4)}$.

In this context, $\mathrm{AE}$ is defined by an incident that results in unnecessary damage to the patient, due to care error, that is, unintentional ${ }^{(5)}$. In Brazil, in 2016, 53,997 incidents related to assistance were notified through the Núcleos de Segurança do Paciente (NSP- Patient Safety Centers) implemented in health services, the majority of which, 50,735, were reported only in hospitals ${ }^{(6)}$. Thus, AE represents a public health problem and one of the challenges inherent to the health care process.

Within a hospital organization, Intensive Care Units (ICUs) are highly complex places, equipped with high technology equipment and responsible for receiving critical and hemodynamically unstable patients. Studies indicate a high incidence of $A E$ in this unit, and according to the Boletim Segurança do Paciente e Qualidade em Serviços de Saúde No.15 (Brazilian Patient Safety and Health Services Quality Bulletin), it is the second hospital unit in notifications, with a total of 15,107 incidents. Some factors can contribute to these numbers, such as the unpreparedness of professionals in the handling of technological equipment, failures in communication between team members and management, structural inadequacies in the work environment, and work overload ${ }^{(6-7)}$.

Unfavorable safety attitudes lead to the occurrence of AE and, as described above, this risk increases in ICUs, however, the risks can be avoided by promoting a safe environment, optimized favorable safety attitudes, especially by the nursing staff, which represents the largest contingent of health professionals within the ICUs and holds the most significant amount of direct patient care in this unit.

\section{OBJECTIVE}

To analyze the patient safety climate in intensive care units from the nursing perspective.

\section{METHODS}

\section{Ethical aspects}

The present study followed the ethical and legal precepts of Resolution 466/2012, of the National Health Council. The project was submitted to the Research Ethics Committee of the State University of Piaui and the Research Ethics Committee of the hospital (coparticipant institution), which approved it on September 24, 2018.

\section{Study Design, location, and period}

Cross-sectional study carried out in three Intensive Care Units (Pediatric, General, and Neurotrauma) of a public hospital for emergency services in a municipality in the northeast of Piauí, from October to November 2018. The study was guided by STROBE.

\section{Population and sample}

The hospital has 906 nursing professionals, and, of these, 111 professionals (nurses, nursing technicians/assistants) work in the ICUs. As it is a finite and relatively small population, it was estimated to work with all professionals who met the inclusion and exclusion criteria. The 111 professionals met the inclusion criteria, and the study excluded 24: 11 professionals were on vacation, six on leave, and seven professionals were absent from the unit at the time of collection, remaining 87 eligible professionals. Figure 1 deals with the sample flowchart used in the study.

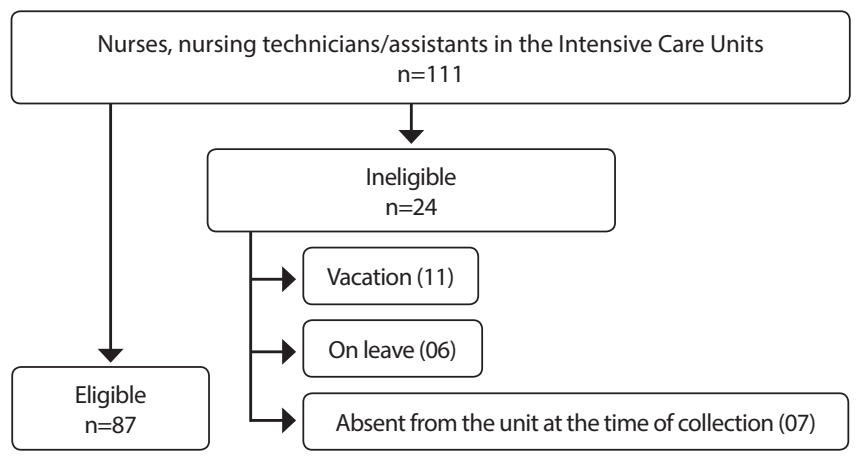

Figure 1 - Flowchart of the sample used in the study, Teresina, Piauí, Brazil, 2019

\section{Inclusion and exclusion criteria}

The inclusion criteria were: being a nurse, nursing technician or nursing assistant who had worked for at least three months in the institution's Intensive Care Unit, with a minimum weekly workload of 20 hours in the unit. The study excluded professionals who, during the data collection period, were on vacation, on leave, absent, or had a medical certificate.

\section{Study Protocol}

Data collection was carried out in October and November 2018. For this purpose, the Safety Attitudes Questionnaire (SAQ) validated and adapted ${ }^{(8)}$ was used, with the due authorization of the Brazilian author. 
As for the content, this instrument consists of two parts: the first contains 36 questions involving the perception of patient safety. The second part aims to collect data from the professional: position held, gender, main practice, and length of work experience. Thus, this instrument measures the perception of health professionals through six domains:

1. Teamwork Climate: considered as the quality of the relationship and the collaboration between the members of a team (items 1 to 6 );

2. Safety Climate: professionals' perception of organizational commitment to patient safety (items 7 to 13 );

3. Job Satisfaction: positive view of the workplace (items 15 to 19);

4. Stress Recognition: recognition of how much stressors can influence the execution of work (items 20 to 23);

5. Perception of Management: approval of the actions of management or administration, both unit in which the professional operates, and of the hospital as a whole (items 24 to 29), item 29 belonging only to the Perception of Unit Management;

6. Working Conditions: perception of the quality of the work environment (items 30 to 32 )

However, items 14, 33 to 36 are not part of any domain in the original instrument, but we considered them when measuring the final mean of the SAQ score.

The answer to each question followed the Likert five-point scale: option A - totally disagrees; B - partially disagrees; C - neutral; D - partially agree; E - totally agree; $X$ - does not apply. The final score of the instrument ranges from 0 to 100 , in which zero corresponds to the worst perception of safety attitudes by health professionals and 100 to the best perception. Positive values are considered when the total score is equal to 75. The scores were ordered as follows: A - totally disagrees, worth 0; B - partially disagrees, worth 25; C - neutral, worth 50; D - partially agrees, worth 75; And - totally agree, worth 100.

Items 2, 11, and 36 are reversed, the completed answers, such as "totally disagree," become "totally agree," and, thus, similarly for the other items. We counted the scores as follows: initially, the reverse items are recoded; subsequently, all items are ordered by domains. Thus, we added and divided the answers to the questions of each domain by the number of questions each domain had. The item "does not apply" was considered as completed data because it has a meaning for the instrument. However, it did not participate in the calculations of mean and score of the scale.

\section{Results analysis and statistics}

The data were analyzed using the software Statistical Package for Social Science (SPSS ${ }^{\circledR}$ ) version 22.0. Then, descriptive analyzes were performed. In the inferential analysis, the Kolmogorov-Smirnov test was performed to verify the normality of the data; We applied it between the domains of the SAQ instrument as a dependent variable and the variables ICU, position, gender, main practice, length of work in the specialty and professional position. For variables that showed normal distribution, parametric tests were used, and those with non-normal distribution non-parametric tests were applied.

We applied the non-parametric test Kruskal-Wallis for the association between the SAQ domains and the ICU characteristics, the main practice, and length of work in the specialty. In the comparison between the domains of the instrument and the variables position and gender, it was applied non-parametric test Mann-Whitney. For the association between the domain "working conditions" and the variable position, the parametric Student t-test was performed.

We created three different databases according to the ICU, for analysis between total SAQ and professional position. In those where there was no normality of data (pediatric and neurotrauma), the Mann-Whitney test was applied, whereas the Student's t-test was used to assess differences between the means of the normal variables ( General ICU). The results of the tests that had a $p$ value less than or equal to 0.05 were considered statistically significant.

\section{RESULTS}

Of the 87 professionals, 31 (35.6\%) worked in the pediatric ICU. As for the previous filling in of the instrument, 86 (98.9\%) professionals declared that they had not completed the instrument before. Regarding the professional category, nursing assistants/ nursing technicians stood out, with $72(82.8 \%)$ participants. The predominant gender was female, with 77 (88.5\%) professionals. Regarding the main practice, 55 (63.2\%) professionals declared to work in adult care, and only 3 (3.4\%) declared to work in both specialties, adult and pediatrics. As for the length of work in the specialty, 43 (49.4\%) stated that they had 5 to 10 years of experience, followed by 25 (28.7\%) professionals who had 11 to 20 years of experience (Table 1 ).

Table 1 - Profile of professionals in the nursing team working in ICUs, Teresina, Piauí, Brazil, 2019

\begin{tabular}{lcc}
\hline Professional profile & $\mathbf{n}$ & $\%$ \\
\hline ICU unit & & \\
$\quad$ Pediatrics & 31 & 35.6 \\
$\quad$ General & 27 & 31.0 \\
$\quad$ Neurotrauma & 29 & 33.3 \\
Have the professionals filled out the instrument before? & & \\
Yes & 1 & 1.1 \\
No & 86 & 98.9 \\
Position & & \\
Nurse & 15 & 17.2 \\
Nursing assistant/nursing technician & 72 & 82.8 \\
Gender & & \\
Male & 10 & 11.5 \\
Female & 77 & 88.5 \\
Main practice & & \\
Adult & 55 & 63.2 \\
Pediatrics & 29 & 33.3 \\
Both & 3 & 3.4 \\
Length of work in the specialty & & \\
6 to 11 months & 2 & 2.3 \\
1 to 2 years & 6 & 6.9 \\
3 to 4 years & 8 & 9.2 \\
5 to 10 years & 43 & 49.4 \\
11 to 20 years & 25 & 28.7 \\
21 years or more & 3 & 3.4 \\
\hline
\end{tabular}


Table 2 - Descriptive analysis of the Safety Attitudes Questionnaire, Teresina, Piauí, Brazil, 2019

\begin{tabular}{lccc}
\hline Domains & Mean & Median & SD \\
\hline Total SAQ & 68.57 & 69.51 & 14.84 \\
Teamwork climate & 80.36 & 83.33 & 14.57 \\
Safety climate & 68.87 & 71.43 & 18.15 \\
Job satisfaction & 86.26 & 90.00 & 12.01 \\
Stress Recognition & 73.20 & 81.25 & 26.99 \\
Perception of Management & & & \\
$\quad$ Unit & 57.63 & 62.50 & 24.35 \\
$\quad$ Hospital & 53.94 & 55.00 & 23.90 \\
Working Conditions & 58.57 & 58.33 & 29.19 \\
Question 14 and 33 To 36 & 66.42 & 70.00 & 20.56 \\
\hline Note: SD-Standard deviation:SAQ- Safety Attitudes Questionnaire. & &
\end{tabular}

The total SAQ score obtained a mean of $68.57(S D=14.84)$ and a median of 69.51 , indicating a negative perception regarding the safety climate in the studied ICUs. The other scores obtained by domains and questions not belonging to the domains (Questions 14 and 33 to 36) presented means below 75 points, indicating negative perceptions regarding the safety climate among nursing professionals, in which the domain related to the Perception of Management was show the one with the lowest scores (Table 2).

Table 3 shows associations between means and standard deviation of the domains and variables: type of ICU, position, gender, main practice, and length of work in the specialty. When comparing the variables and domains of the SAQ, as well as the scores of the Total SAQ, we found that there was no statistical difference concerning the variables position and gender.

Table 3 - Scores by domain, distributed by ICU type, position, gender, main practice, and length of work in the specialty, Teresina, Piauí, Brazil, 2019

Domains

\begin{tabular}{|c|c|c|c|c|c|c|c|c|}
\hline \multirow[t]{2}{*}{ Variables } & \multirow{2}{*}{$\begin{array}{l}\text { Total SAQ } \\
\text { Mean } \pm \text { SD } \\
\text { ( } p \text { value) }\end{array}$} & \multirow{2}{*}{$\begin{array}{l}\text { Teamwork } \\
\text { climate } \\
\text { Mean } \pm \text { SD } \\
\text { (p value) }\end{array}$} & \multirow{2}{*}{$\begin{array}{c}\text { Safety } \\
\text { climate } \\
\text { Mean } \pm \text { SD } \\
\text { ( } p \text { value) }\end{array}$} & \multirow{2}{*}{$\begin{array}{c}\text { Job } \\
\text { satisfaction } \\
\text { Mean } \pm \text { SD } \\
\text { (p value) }\end{array}$} & \multirow{2}{*}{$\begin{array}{c}\text { Stress } \\
\text { Recognition } \\
\text { Mean } \pm \text { SD } \\
\text { (p value) }\end{array}$} & \multirow{2}{*}{$\begin{array}{l}\text { Perception of } \\
\text { Management } \\
\text { (Unit) } \\
\text { Mean } \pm \text { SD } \\
\text { ( } p \text { value) }\end{array}$} & \multirow{2}{*}{$\begin{array}{l}\text { Perception of } \\
\text { Management } \\
\text { (Hospital) } \\
\text { Mean } \pm \text { SD } \\
\text { (p value) }\end{array}$} & \multirow{2}{*}{$\begin{array}{c}\text { Working } \\
\text { conditions } \\
\text { Mean } \pm \text { SD } \\
\text { ( } p \text { value) }\end{array}$} \\
\hline & & & & & & & & \\
\hline \multicolumn{9}{|l|}{ ICU } \\
\hline Pediatrics & $61.83 \pm 15.77$ & $72.85 \pm 15.84$ & $61.11 \pm 18.18$ & $82.60 \pm 13.78$ & $78.23 \pm 24.63$ & $45.62 \pm 28.72$ & $47.18 \pm 26.37$ & $48.92 \pm 27.53$ \\
\hline General & $71.30 \pm 13.56$ & $88.58 \pm 7.72$ & $69.33 \pm 18.22$ & $89.44 \pm 10.68$ & $65.05 \pm 35.0$ & $60.65 \pm 20.16$ & $53.15 \pm 23.75$ & $64.20 \pm 25.61$ \\
\hline Neurotrauma & $\begin{array}{c}73.66 \pm 12.44 \\
(<0.001)^{1}\end{array}$ & $\begin{array}{c}80.75 \pm 14.15 \\
(0.006)^{1}\end{array}$ & $\begin{array}{c}76.72 \pm 14.77 \\
(0.197)^{1}\end{array}$ & $\begin{array}{l}87.24 \pm 10.40 \\
(0.422)^{1}\end{array}$ & $\begin{array}{c}75.43 \pm 18.82 \\
(0.008)^{1}\end{array}$ & $\begin{array}{l}67.67 \pm 16.95 \\
(0.127)^{1}\end{array}$ & $\begin{array}{c}61.90 \pm 19.24 \\
(0.065)^{1}\end{array}$ & $\begin{array}{c}63.65 \pm 32.18 \\
(0.007)^{1}\end{array}$ \\
\hline \multicolumn{9}{|l|}{ Position } \\
\hline Nurse & $69.72 \pm 13.64$ & $79.17 \pm 13.27$ & $69.52 \pm 16.36$ & $83.67 \pm 16.09$ & $78.33 \pm 18.43$ & $66.94 \pm 19.32$ & $56.67 \pm 20.93$ & $52.50 \pm 28.60$ \\
\hline $\begin{array}{l}\text { assistant / nursing } \\
\text { technician }\end{array}$ & $\begin{array}{c}68.51 \pm 15.16 \\
(0.603)^{2}\end{array}$ & $\begin{array}{c}80.61 \pm 14.90 \\
(0.835)^{2}\end{array}$ & $\begin{array}{c}68.73 \pm 18.60 \\
(0.699)^{2}\end{array}$ & $\begin{array}{c}86.80 \pm 11.05 \\
(0.750)^{2}\end{array}$ & $\begin{array}{c}72.14 \pm 28.44 \\
(0.131)^{2}\end{array}$ & $\begin{array}{l}55.69 \pm 24.95 \\
(0.744)^{2}\end{array}$ & $\begin{array}{c}53.37 \pm 24.58 \\
(0.343)^{2}\end{array}$ & $\begin{array}{c}59.84 \pm 29.35 \\
(0.776)^{3}\end{array}$ \\
\hline \multicolumn{9}{|l|}{ Gender } \\
\hline Male & $66.69 \pm 11.66$ & $80.42 \pm 13.47$ & $65.36 \pm 22.78$ & $87.50 \pm 10.87$ & $79.38 \pm 20.21$ & $55.83 \pm 21.44$ & $49.00 \pm 16.63$ & $46.67 \pm 24.28$ \\
\hline Female & $\begin{array}{c}68.98 \pm 15.24 \\
(0.799)^{2}\end{array}$ & $\begin{array}{c}80.36 \pm 14.79 \\
(0.754)^{2}\end{array}$ & $\begin{array}{c}69.33 \pm 17.59 \\
(0.856)^{2}\end{array}$ & $\begin{array}{c}86.10 \pm 12.21 \\
(0.484)^{2}\end{array}$ & $\begin{array}{c}72.40 \pm 27.75 \\
(0.704)^{2}\end{array}$ & $\begin{array}{c}57.87 \pm 24.82 \\
(0.333)^{2}\end{array}$ & $\begin{array}{c}54.58 \pm 24.71 \\
(0.168)^{2}\end{array}$ & $\begin{array}{c}60.12 \pm 29.55 \\
(0.648)^{2}\end{array}$ \\
\hline \multicolumn{9}{|l|}{ Main practice } \\
\hline Adult & $72.31 \pm 12.95$ & $84.39 \pm 12.14$ & $73.00 \pm 16.90$ & $88.09 \pm 10.47$ & $70.23 \pm 28.26$ & $63.94 \pm 18.72$ & $57.28 \pm 21.77$ & $63.56 \pm 29.08$ \\
\hline Pediatrics & $63.45 \pm 14.98$ & $75.27 \pm 13.17$ & $62.13 \pm 18.38$ & $83.79 \pm 13.41$ & $76.72 \pm 24.77$ & $48.19 \pm 27.88$ & $50.43 \pm 23.98$ & $51.15 \pm 27.07$ \\
\hline Both & $\begin{array}{c}53.66 \pm 26.41 \\
(0.001)^{1}\end{array}$ & $\begin{array}{c}55.56 \pm 31.28 \\
(0.026)^{1}\end{array}$ & $\begin{array}{c}58.33 \pm 20.62 \\
(0.314)^{1}\end{array}$ & $\begin{array}{c}76.67 \pm 20.21 \\
(0.201)^{1}\end{array}$ & $\begin{array}{c}93.75 \pm 10.83 \\
(0.029)^{1}\end{array}$ & $\begin{array}{c}33.33 \pm 43.30 \\
(0.270)^{1}\end{array}$ & $\begin{array}{c}26.67 \pm 46.19 \\
(0.080)^{1}\end{array}$ & $\begin{array}{c}38.89 \pm 38.49 \\
(0.015)^{1}\end{array}$ \\
\hline \multicolumn{9}{|l|}{$\begin{array}{l}\text { Length of work in the } \\
\text { specialty }\end{array}$} \\
\hline 6 to 11 months & $66.77 \pm 14.23$ & $85.42 \pm 20.63$ & $48.21 \pm 22.73$ & $92.50 \pm 3.53$ & $71.88 \pm 39.77$ & $47.92 \pm 32.41$ & $55.00 \pm 21.21$ & $70.84 \pm 29.47$ \\
\hline 1 to 2 years & $61.99 \pm 9.47$ & $75.00 \pm 18.82$ & $60.12 \pm 11.39$ & $78.33 \pm 13.29$ & $63.54 \pm 19.13$ & $52.08 \pm 14.13$ & $50.83 \pm 13.20$ & $38.89 \pm 35.62$ \\
\hline 3 to 4 years & $80.51 \pm 9.82$ & $89.06 \pm 9.70$ & $75.45 \pm 18.36$ & $95.00 \pm 3.78$ & $73.44 \pm 38.50$ & $76.56 \pm 21.12$ & $75.63 \pm 15.68$ & $78.12 \pm 17.78$ \\
\hline 5 to 10 years & $69.65 \pm 14.52$ & $81.78 \pm 14.17$ & $68.04 \pm 20.04$ & $87.79 \pm 12.92$ & $74.42 \pm 27.84$ & $59.50 \pm 23.10$ & $55.81 \pm 21.29$ & $61.43 \pm 28.23$ \\
\hline 11 to 20 years & $64.33 \pm 16.56$ & $76.00 \pm 15.18$ & $70.07 \pm 14.66$ & $81.40 \pm 10.16$ & $72.00 \pm 24.75$ & $49.57 \pm 26.91$ & $44.90 \pm 28.69$ & $51.67 \pm 28.67$ \\
\hline 21 years or more & $\begin{array}{l}75.27 \pm 8.04 \\
(0.347)^{1}\end{array}$ & $\begin{array}{c}80.55 \pm 4.81 \\
(0.124)^{1}\end{array}$ & $\begin{array}{l}84.52 \pm 12.54 \\
(0.019)^{1}\end{array}$ & $\begin{array}{c}93.33 \pm 2.87 \\
(0.651)^{1}\end{array}$ & $\begin{array}{c}85.42 \pm 15.73 \\
(0.064)^{1}\end{array}$ & $\begin{array}{c}65.28 \pm 20.55 \\
(0.047)^{1}\end{array}$ & $\begin{array}{c}50.00 \pm 25.00 \\
(0.127)^{1}\end{array}$ & $\begin{array}{c}54.17 \pm 41.04 \\
(0.081)^{1}\end{array}$ \\
\hline
\end{tabular}

Note: SD-Standard Deviation; 1 - Kruskal Wallis test; 2 - Mann-Whitney U test; 3 - Student's T-test

Table 4 - Association between ICU types and professional positions according to the mean of the total SAQ, Teresina, Piauí, Brazil, 2019

\begin{tabular}{|c|c|c|c|c|c|c|}
\hline \multirow[t]{2}{*}{ Professional position } & \multicolumn{6}{|c|}{ Type of ICU } \\
\hline & Mean \pm SD & $p$ value ${ }^{1}$ & Mean \pm SD & $p$ value $^{2}$ & Mean \pm SD & $p$ value ${ }^{1}$ \\
\hline Nurse & $65.09 \pm 13.10$ & 0.548 & $68.30 \pm 11.90$ & 0.576 & $74.53 \pm 15.73$ & 0.813 \\
\hline Nursing assistant / nursing technician & $61.22 \pm 16.38$ & & $71.83 \pm 14.00$ & & $73.44 \pm 11.85$ & \\
\hline
\end{tabular}

Note: 1 - Mann-Whitney U test; 2 - Student's t-test 
The variable referring to the type of ICU showed a statistical difference in association with the Total SAQ scores $(p=<0.001)$ and the domains Teamwork Climate $(p=0.006)$, Stress Recognition $(p=0.008)$ and Working Conditions $(p=0.007)$. The Pediatric ICU showed the worst Patient Safety Climate among professionals with a Total SAQ mean of $61.83(S D=15.77)$, the worst perception about the Teamwork Climate, and the worst perception about Working Conditions. General ICU had the worst perception of Stress Recognition with a mean of $65.05(S D=35.0)$. The other domains associated with the type of ICU variable did not show statistical differences.

In the association of the variable length of work in the specialty with the domains and scores of the Total SAQ, only the domains Safety Climate $(p=0.019)$ and Perception of the Unit Management $(p=0.047)$ showed statistical differences. The other domains associated with the variable length of work in the specialty did not show statistical differences.

The domains of Job Satisfaction and Perception of Hospital Management did not show any statistical difference in association with the studied variables.

Table 4 lists the three ICUs with the respective positions of nurses and nursing assistants/nursing technicians, revealing that there were no significant statistical influences, that is, the professional position had no direct influence on the SAQ results for each ICU.

\section{DISCUSSION}

The present study analyzed the patient safety climate in the ICU from the perspective of nursing professionals and found that this climate is negative, revealing an unfavorable perception, especially in the domains of Safety Climate, Perception of Management and Working Conditions.

Regarding the total SAQ score, the results indicated a negative perception in relation to the safety climate in the studied ICUs. This data corroborated national and international studies ${ }^{(9-12)}$, which, when measuring the patient's safety climate among the professionals, obtained scores below 75 points, indicating negative perceptions and weaknesses regarding patient care provided by health teams, especially nursing. As for the scores found according to the domains, we observed that the best perceptions on the safety climate in the studied ICUs were obtained in the first and third domains. This last domain, related to Job Satisfaction, presented the highest score achieved in the study with a mean of 86.26 and a median of 90.00; and the one, related to the Teamwork Climate, had a mean of 80.36 and a median of 83.33, showing the second-highest score found.

Job satisfaction also becomes an indicator of the quality of service provision. As a result, organizations must make efforts to improve structure and resource conditions in professional environments, and for teamwork to be developed through effective communication to reflect on mutual collaboration between professionals, providing positive results, such as Job satisfaction and efficiency in activities ${ }^{(13-14)}$.

It appears that the domain related to Perception of Management had the lowest scores, both in Perception of Unit Management with a mean of 57.63 and a median of 62.50, and in Perception of Hospital Management with a mean of 53.94 and median of 55.00. In this domain, there was a more significant proportion of professionals with negative perceptions concerning the management of the unit and hospital. A study carried out in a public teaching hospital located in the Triângulo Mineiro region, in the state of Minas Gerais and a study carried out in Adult, Coronary and Neonatal ICUs, also in the Triângulo Mineiro region, observed lower means, being 52.4 and 51.01, respectively ${ }^{(15-16)}$.

These findings indicate the need for managers to broaden their perspectives on these issues, considering that the change process involves security attitudes in an individual and institutional context ${ }^{(17-18)}$. This distance may occur due to the culture that errors must be corrected through punishment, without assessing the circumstances in which the incident occurred. Thus, there is a need to assess the attitudes presented by management in relation to questions about patient safety and their relationship with nursing professionals ${ }^{(19)}$.

The Safety Climate domain had a mean of 68.87. This domain is related to the professionals' perception of the organizational commitment to patient safety, revealing a negative perception, similar to the findings of national studies ${ }^{(13,15,20)}$. It is worth highlight that the safety climate is a reflection of safe care for patients. In this way, healthcare organizations are strongly and actively committed to ensuring this security.

Concerning the domain Stress Recognition, the score obtained was 73.20 ( $S D=26.09$ ). This domain is related to the recognition of how much stressors can influence the execution of work. National and international studies show similarities between the scores obtained with means of 64.9 and 67.5 , respectively ${ }^{(11.15)}$.

Thus, considering the values of the scores obtained for each domain of the general SAQ (for the three ICUs studied), whose scores $>75$ indicate the best perception and scores $<75$ indicate the worst perception, we interpreted that there is a good relationship and collaboration between members of the nursing team in the ICUs (mean 80.36). Nursing professionals have an unfavorable perception of the ncommitment to patient safety in the unit they work in (mean 68.87). The nursing team sees their workplace positively (mean 86.26). Nursing professionals do not recognize how much stressors can influence on work performance (mean 73.20). Nursing professionals do not approve the actions of management or administration, both in the unit where the professional work, and in the hospital as a whole, the gap between management and professionals in the work environment is notorious - mean 57.63 (Unit) / 53.94 (Hospital). The nursing team does not consider their work environment to be of good quality (mean 58.57).

The type of ICU showed statistical difference in association with the SAQ scores and the domains Teamwork Climate, Stress Recognition and Working Conditions, in which the Pediatric ICU had the worst Patient Safety Climate among professionals, the worst perception of the Teamwork Climate and the worst perception of Working Conditions. It also stands out the General ICU with the worst perception about the stress recognition. Data similar to those previously mentioned, related to pediatric care, were found in a national study, which obtained a mean total SAQ of 67.72 , revealing a negative perception about the patient safety climate among professionals ${ }^{(21)}$. 
There was a statistical difference between the main practice and the SAQ Total scores and the domains of Teamwork Climate, Stress Recognition and Working Conditions domains, in which the professionals who claimed to work in both specialties (adult and pediatric) had the lowest scores for Total SAQ scores with a mean of 53.66, for Teamwork Climate, with a mean of 55.56, and for Working Conditions with a mean of 38.89. The nursing professionals who claimed to work in the adult specialty had the worst perception related to the stress recognition, with a mean of 70.23. The other domains associated with the type of ICU variable did not show statistical differences.

In the literature, we did not identify results similar to this finding considering the association with the main practice in both specialties. However, a national study carried out in three ICUs of a public teaching hospital in the municipality of Sumaré, state of São Paulo, revealed an approximation with the results of this study, although separately, with emphasis on pediatrics, with values for domains with the same proportions ${ }^{(21)}$.

Regarding the association between the variable length of work in the specialty and the domains and scores of the Total SAQ, only the domains Safety Climate and Perception of the Unit's Management showed statistical differences. In which the professionals working in the specialty from 6 to 11 months presented the lowest scores for the domains related to the Safety Climate and the Perception of the Unit's Management, with a mean of 48.21 and 47.93 , respectively. In contrast, professionals who worked 21 or more in the specialty had the best perception related to the Safety Climate, with a mean of 84.52, and nursing professionals who worked 3 to 4 years in the specialty showed to have better scores concerning the Perception of the Unit Management, with a mean of 76.56.

The total SAQ scores for the domains and the variable time in the specialty that showed statistical influence corroborate the national study carried out in a mental health hospital, a benchmark for psychiatric care in the state of Ceará, located in Fortaleza ${ }^{(20)}$.

It is worth mentioning that the domains of Job Satisfaction and Perception of Hospital Management did not show any statistical difference in association with the studied variables, indicating that these variables have no direct influence on professional perception related to job satisfaction and the perception of hospital management. However, even though there is no statistical influence, it is important to highlight that, for all studied variables, the domain related to job satisfaction obtained positive scores ( $>75$ points) and the domain related to Perception of Hospital Management obtained negative scores ( $<75$ points) corroborating several national studies ${ }^{(3,15,21-23)}$.
Observing the values of Total SAQ for the three studied ICUs and the scores for professional position distributed by ICU, it appears that there were no discrepancies about the patient safety climate perceived by the nursing team, presenting homogeneous results, below 75 points, revealing the unfavorable safety climate perceived by nursing professionals in the units under study.

\section{Study Limitations}

The study was carried out in a single unit, from a single institution, which makes it difficult to generalize.

\section{Contributions to the nursing field}

The contributions of this study to nursing relate to the knowledge generated by obtaining the results. They may contribute to the development of strategies for permanent education and awareness of the nursing team regarding the attitudes for patient's safety in intensive care. Such strategies aim to ensure improvements in the work process and promote patient safety climate and culture within the health service.

\section{CONCLUSION}

The analysis of the patient safety climate from the perspective of the nursing staff in the studied intensive care units was negative, revealing an unfavorable perception, especially in the domains of Safety Climate, Perception of Management and Working Conditions. There were no statistical differences in domain scores between pediatric, general, and neurotrauma ICUs, nor between professional categories (nurses and nursing assistants/nursing technicians).

The domain related to Job Satisfaction stood out, which reached scores higher than 75 points, revealing that despite the various problems existing in the workplace, professionals are satisfied with their profession, and this is the first step to promote necessary changes - both in the hospital organization and the safety culture to be developed by them.

For improvements in the safety climate, it is necessary to qualify the assistance provided to the patient, promote communication between professionals and the different units, recognize and consider the importance of the involvement of all professionals in decision-making, adopt instruments for assessing teamwork, introduce non-punitive measures to the possible mistakes that will come and reward teams with the best performances.

\section{REFERENCES}

1. Silva AMB, Bim LL, Bim FL, Sousa AFL, Domingues PCA, Nicolussi AC, et al . Patient safety and infection control: bases for curricular integration. Rev Bras Enferm. 2018;71(3):1170-7. doi: 10.1590/0034-7167-2017-0314

2. Göras C, Unbeck M, Nilsson U, Ehrenberg A. Interprofessional team assessments of the patient safety climate in Swedish operating rooms: a cross-sectional survey. BMJ open [Internet]. 2017 [cited 2019 Jul 03];7(9):1-9. doi: 10.1136/bmjopen-2016-015607

3. Toso GL, Golle L, Magnago TSBS, Herr GEG, Loro MM, Aozane F, et al. Cultura de segurança do paciente em instituições hospitalares na perspectiva da enfermagem. Rev Gaúcha Enferm. 2016;37(4):1-10. doi: 10.1590/1983-1447.2016.04.58662

4. Weng SJ, Kim SH, Wu CL. Underlying influence of perception of management leadership on patient safety climate in healthcare organizations-A mediation analysis approach. Int J Qual Health Care. [Internet]. 2017 [cited 2019 Jul 29]; 29(1):111-116. doi: 10.1093/intqhc/mzw145 
5. Brasil. Agência Nacional de Vigilância Sanitária. Implantação do Núcleo de Segurança do Paciente em Serviços de Saúde - Série Segurança do Paciente e Qualidade em Serviços de Saúde. Brasília, DF: ANVISA; 2016. Available from: http://portal.anvisa.gov.br/ documents/33852/3507912/Caderno+6+-+Implanta\%C3\%A7\%C3\%A3o+do+N\%C3\%BAcleo+de+Seguran\%C3\%A7a+do+Paciente+em+S ervi\%C3\%A7os+de+Sa\%C3\%BAde/cb237a40-ffd1-401f-b7fd-7371e495755c

6. Wichmann D, Belmar Campos CE, Ehrhardt S, Kock T, Weber C, Rohde H, et al. Efficacy of introducing a checklist to reduce central venous line associated bloodstream infections in the ICU caring for adult patients. BMC Infect Dis. 2018;8;18(1):267. doi: 10.1186/ s12879-018-3178-6

7. Mansour MJ, Al Shadafan SF, Abu-Sneineh FT, AlAmer MM. Integrating Patient Safety Education in the Undergraduate Nursing Curriculum: A Discussion Paper. Open Nurs J. 2018;12:125-32. doi: 10.2174/1874434601812010125

8. Carvalho REFL, Cassiani SHB. Questionário Atitudes de Segurança: adaptação transcultural do Safety Attitudes Questionnaire - Short Form 2006 para o Brasil. Rev Latino-Am Enfermagem. 2012;20(3):575-82. doi: 10.1590/S0104-11692012000300020

9. Abdi Z, Delgoshaei B, Ravaghi H, Abbasi M, Heyrani A. The culture of patient safety in an Iranian intensive care unit. J Nurs Manag [Internet]. 2015[cited 2019 Jul 03];23:333-45. Available from: https://www.ncbi.nlm.nih.gov/pubmed/23902287

10. Gasparino RC, Bagne BM, Gastaldo LS, Dini AP. Percepção da enfermagem frente ao clima de segurança do paciente em instituições públicas e privadas. Rev Gaúcha Enferm. 2017;38(3):1-19. doi: 10.1590/1983-1447.2017.03.68240

11. Rigobello MCG, Carvalho REFL, Guerreiro JM, Motta APG, Atila E, Gimenes FRE. The perception of the patient safety climate by professionals of the emergency department. Int Emerg Nurs. 2017;33(1):1-6. doi: 10.1016/j.ienj.2017.03.003

12. Marinho, MM, Radünz V, Rosa LM, Tourinho FSV, Ilha P, Misiak M. Intervenções educativas com profissionais de enfermagem e sua relação com a cultura de segurança. Rev Min Enferm. 2018;22(1):1-8. doi: 10.5935/1415-2762.20180079

13. Águas R, Araújo CAC, Soares S. Questionário de Atitudes de Segurança - Versão Cuidados Intensivos: adaptação e validação para a população portuguesa. Rev Enferm Ref. 2017;4(15):101-8. doi: 10.12707/RIV17041

14. Tondo JCA, Guirardello EB. Percepção dos profissionais de enfermagem sobre a cultura de segurança do paciente. Rev Bras Enferm. 2017;70(6):1284-90. doi: 10.1590/0034-7167-2016-0010

15. Luiz RB, Simões ALA, Barichello E, Barbosa MH. Fatores associados ao clima de segurança do paciente em um hospital de ensino. Rev LatinoAm Enfermagem. 2015;23(5):880-7. doi: 10.1590/0104-1169.0059.2627

16. Reis FFP, Oliveira KF, Luiz RB, Barichello E, Cruz LF, Barbosa MH. Cultura de segurança em unidades de terapia intensiva. Rev Enferm Atenç Saúde. 2017;6(2):34-48. doi: 10.18554/reas.v6i2.1991

17. Amaral LR, Araújo CAS. Advanced practices and patient safety: an integrative literature review. Acta Paul Enferm. 2018;31(6):688-95. doi: 10.1590/1982-0194201800094

18. Galhardi NM, Roseira CE, Orlandi FS, Figueiredo RM. Assessment of the patient safety culture in primary health care. Acta Paul Enferm. 2018;31(4):409-16. doi: 10.1590/1982-0194201800057

19. Golle L, Ciotti D, Herr GEG, Aozane F, Schmidt CR, Kolankiewicz ACB. Cultura de segurança do paciente em hospital privado. Rev Pesqui: Cuid Fundam. 2018;10(1):85-9. doi: 10.9789/2175-5361.2018.v10i1.85-89

20. Oliveira ICL, Cavalcante MLSN, Aires SF, Freitas RJM, Silva BV, Marinho DMF. Cultura de segurança: percepção dos profissionais de saúde em um hospital mental. Rev Bras Enferm. 2018;71(Suppl 5):2316-22. doi: 10.1590/0034-7167-2018-0125

21. Santiago THR, Turrini RNT. Cultura e clima organizacional para segurança do paciente em Unidades de Terapia Intensiva. Rev Esc Enferm USP. 2015;49(spe):123-30. doi: 10.1590/S0080-623420150000700018

22. Barbosa MH, Sousa EM, Felix MMS, Oliveira KF, Barichello E. Clima de segurança do paciente em um hospital especializado em oncologia. Rev Eletron Enferm. 2015;17(4):1-9. doi: 10.5216/ree.v17i4.xxx

23. Barbosa MH, Aleixo TC, Oliveira K, Nascimento K, Felix M, Barichello E. Clima de segurança do paciente em unidades de clínica médica e cirúrgica. Rev Eletron Enferm. 2016;18(1):1-10. doi: 10.5216/ree.v18.39763 